\title{
Pemanfaatan Marka RAPD untuk Mengestimasi Diversitas Genetik Progeni Half-Sib Paraserianthes falcataria (L.) Nielsen Hasil Seleksi Ketahanan Boktor dan Riap Pertumbuhan
}

\author{
Utilization of RAPD Marker for Genetic Diversity Estimation of \\ Paraserianthes falcataria (L.) Nielsen Half-Sib Progeny Following \\ Selection to Stem Borer Resistance and Growth Increament
}

\author{
N. Rostini ${ }^{1}$, S. Sunarya ${ }^{2}$, Murdaningsih H.K. ${ }^{1}$, Anas ${ }^{1}$, dan F. Damayanti ${ }^{1}$ \\ 'Fakultas Pertanian Universitas Padjadjaran \\ ${ }^{2}$ Sekolah Ilmu dan Teknologi Hayati ITB
}

\begin{abstract}
Genetic diversity measurement of Paraserianthes falcataria half-sib progeny is required to study the genetic quality to support tree improvement programme, plantation and seed source development in tree breeding. To investigate the genetic diversity of half-sib progeny, Random Amplified Polymorphic DNA (RAPD) molecular marker can be utilized. This study aimed to estimate the genetic diversity of P. falcataria half-sib progeny population from four different provenances, i.e., Banjarnegara provenance, Subang provenance, Kediri provenance, and Kuningan provenance, following selection to stem borer and growth increment. Leaf samples of 160 seedlings were collected from 16 parents, four parents from each origin. Genetic diversity was analyzed using four RAPD primers with 30 polymorphic loci. The result showed that the genetic diversity of the half-sib progeny population for each parameter was $\mathrm{PP} / \mathrm{L}=1.82, \mathrm{PPL}=77.50 \%$, and $\mathrm{He}=0.240$. Genetic distance among the population was ranged between 0.025 and 0.140 by Gregorius (1974), on the other hand, the genetic distance among the population was varied between 0.094 and 0.266 by Nei (1972). Some half-sib progeny from the same parents were grouped in the same cluster. Therefore, the clustering of the provenance had no relationship with the source of geographic distribution. Genetic relationship among half-sib progeny population was divided into three groups by Nei (1972). The first group consisted of Banjarnegara and Subang half-sib progeny, the second group was Kediri half-sib progeny, and the third group was Kuningan half-sib progeny.
\end{abstract}

Keywords : Genetic diversity, Paraserianthes falcataria, Progeny half-sib RAPD

\begin{abstract}
Abstrak: Diversitas genetic pada progeni half sib dari Paraserianthes falcataria diperlukan untuk mendukung program pemuliaan pada albasia. Tujuan penelitian untuk mengestimasi diversitas genetik berdasarkan Random Amplified Polymorphic DNA (RAPD) dari progeni half sib P. falcataria pada empat provenan yang berbeda, yaitu : Banjarnegara, Subang, Kediri dan Kuningan dari albasia yang telah diseleksi tahan terhadap boktor dan riap pertumbuhan. Sampel daun diambil dari 160 kecambah yang dikoleksi dari 16 tetua dengan empat tetua dari masing masing provenan. RAPD menggunakan 30 praimer polimorfik. Hasil penelitian menunjukkan diversitas genetik berdasarkan Random Amplified Polymorphic DNA (RAPD) dari progeni half sib P. falcataria adalah $\mathrm{PP} / \mathrm{L}=1.82, \mathrm{PPL}=77.50 \%$ dan $\mathrm{He}=0.240$. Jarak genetik antar populasi berkisar antara 0.025 sampai 0.140 berdasarkan Gregorius (1974), dan antara 0.094 sampai 0.266 berdasarkan Nei (1972). Beberapa progeni half sib dari tetua yang sama berada pada kluster yang sama. Pengklusteran provenan tidak berhubungan dengan distribusi berdasarkan geografi. Kekerabatan genetik di antara progeni half sib terbagi menjadi tiga grup berdasarkan Nei (1972). Progeny dari Kediri dan grup ketiga dari Kuningan.
\end{abstract}

Kata kunci: Diversitas genetik, Paraserianthes falcataria, Progeni half sib, RAPD

\section{Pendahuluan}

Paraserianthes falcataria atau albasia, banyak ditanam di seluruh Indonesia. Penanaman albasia di Baduy luar Jawa Barat meningkatkan ekonomi petani karena ditanam di antara pertanaman padi, sehingga petani mendapat nilai tambah dari pemanfaatan lahannya (Iskandar dan Ellen, 2000). Di Jawa Tengah, pemenuhan pasar kayu dipenuhi oleh pengelola kecil yang mengelola berbagai jenis 
kayu, misalnya albasia, meranti atau jati, sehingga diperlukan suatu komunitas sesuai dengan nilai komesial dari kayu (Irawanti et al., 2014). Tingginya permintaan Paraserianthes falcataria ternyata belum diimbangi oleh pemuliaan pada spesies tersebut yang berakibat pada rendahnya produktivitas lahan dan hutan. Pertumbuhan $P$. falcataria dihadapkan terhadap permasalahan pertumbuhan yang tidak seragam serta serangan hama boktor (Xystrocera pestiva) yang dapat menurunkan nilai ekonomis. Nilai ekonomi albasia tidak setinggi jati, karena selain stuktur kayunya yang rapat, jati memiliki lingkaran (cincin) pertmbuhan yang jelas, sedangkan Neolamarckia cadamba, Octomeles sumatrana, dan Paraserianthes falcataria tidak memiliki cincin pertumbuhan (Nordahlia et al., 2014). Ketebalan dinding sel dan serat kayu albasia konstan dari bagian empulur sampai $10 \mathrm{~cm}$ dan ketebalan serta serat kayunya meningkat kearah kulit luar (Ishiguri et al., 2009). Akan tetapi, dengan kandungan holoselulosa tinggi $(85,22 \%-88,88 \%)$ dan kandungan ekstraktif rendah $(1,27 \%-1,73 \%)$ maka albasia sangat sesuai untuk produksi pulp (Muslyza Che Hussin dkk., 2014).

Keterbatasan sumber benih bergenetik unggul juga menjadi faktor pembatas lainnya. Faktor keterbatasan sumber benih diindikasikan oleh hanya terdapat 6 tegakan sumber benih dengan klasifikasi Tegakan Benih Teridentifikasi. Tegakan Benih Teridentifikasi merupakan sumber benih dengan kualitas genetik paling rendah (Balai Perbenihan Tanaman Hutan Jawa-Madura, 2009). Upaya pemuliaan melalui sumber benih telah dapat meningkatkan pertumbuhan menjadi 27.26 $\mathrm{m}^{3} / \mathrm{ha} /$ tahun dibandingkan tanpa pemuliaan yang rata-rata hanya mencapai $20 \mathrm{~m}^{3} / \mathrm{ha} /$ tahun (Rimbawanto, 2008). Keberhasilan pemuliaan pada tanaman hutan adalah Pinus taeda di Amerika Serikat bagian Selatan pada generasi pertama telah meningkat volumenya sebesar $7-12 \%$. Investasi untuk pemuliaan sebesar $\$ 5-6$ per acre $(0,4$ ha) berdampak terhadap peningkatan keuntungan sebesar 18-19\%. Pinus radiata di New Zaeland dan Australia melalui program pemuliaan selama kurun waktu 20 tahun telah meningkatkan volume sebesar 20\% (Hardiyanto, 1994).

Upaya pemuliaan sumber benih $P$. falcataria telah dimulai pada akhir tahun 1999 atau awal tahun 2000. Sumber benih dibangun dengan uji keturunan (progeny tes) hasil seleksi pohon plus pada sebaran hutan rakyat di Banjarnegara, Subang, Kediri dan Kuningan. Penelitian-penelitian maupun aktivitasaktivitas pemuliaan yang mengarah pada pembangunan sumber benih berkarakter tahan boktor dan riap pertumbuhan telah dilakukan melalui seleksi masa maupun pemanfaatan marka isozim. Hasil analisis marka isozim tegakan benih tersebut memiliki diversitas genetik yang rendah dengan nilai $\mathrm{He}=0.053$ (5.30\%) (Sunarya, 2005). Hasil tersebut berbeda dengan hasil penelitian lainnya pada jenis yang sama sebagaimana dilakukan Seido et. al. (1993) dengan menggunakan marka RAPD, diperoleh nilai $\mathrm{He}=0.163 \quad(16.30 \%)$. Penelitian lainnya juga menunjukkan hasil yang berbeda seperti yang dilakukan Wulan (2003); Winarni (2003) dan Dwiyanti (2009) melalui marka isozim yang memperoleh nilai He masing-masing : $0.172(17.20 \%), 0.22(22.00 \%)$ dan 0.2183 (21.83\%).

Tegakan benih $P$. falcataria saat penelitian ini telah dapat memproduksi benih yang diduga memiliki material genetik yang lebih baik sebagai implikasi aktivitas-aktivitas pemuliaan yang telah diaplikasikan sebagaimana dikemukan Falconer (1989), perpindahan genotipe dari tetua dapat menghasilkan susunan genotipe yang beda pada keturunannya. Progeni half-sib yang diperoleh menjadi material yang harus dipelajari diversitas genetiknya untuk menghindari progeni yang mewarisi sifat inferior maupun sebagai tolok ukur keberhasilan program pemuliaan. Diversitas genetik merupakan landasan bagi pemulia untuk memulai kegiatan perbaikan tanaman dan menduga keberhasilan perbaikan genetik di dalam program pemuliaan tanaman. Kepentingan diversitas genetik bagi tanaman dikemukan oleh Finkeldey dan Hattemer (1993), bahwa diversitas genetik merupakan modal dasar bagi suatu jenis tanaman untuk tumbuh, berkembang dan bertahan hidup dari generasi ke generasi. Semakin tinggi diversitas genetik, semakin besar peluang jenis tanaman tersebut dapat beradaptasi dengan kondisi lingkungannya.

RAPD merupakan salah satu penanda DNA yang menawarkan alternatif analisis variabilitas genetik (DNA fingerprint) yang lebih baik terutama untuk mengkarakterisasi suatu populasi tanaman karena mampu menghasilkan polimorfisme pita DNA dalam jumlah banyak dan tidak dipengaruhi oleh faktor lingkungan. Penanda RAPD merupakan penanda berbasis teknologi PCR (Polymerase Chain Reaction) yang mampu mengamplifikasi sekuen DNA tertentu secara in vitro (Weising et al., 1995). Penggunaan penanda RAPD relatif sederhana, mudah dalam preparasinya serta memberikan hasil lebih cepat dibandingkan penanda molekuler lainnya. Untuk tanaman tahunan, RAPD sangat membantu dalam peningkatan efisiensi pada seleksi awal (Grattapaglia dan Sederoff, 1992).

Penelitian bertujuan untuk mengestimasi diversitas genetik dan pola kekerabatan populasi 
progeni half-sib tetua-tetua terseleksi tahan boktor dan riap pertumbuhan tinggi pada tegakan benih uji provenan $P$. falcataria menggunakan marker RAPD untuk mendukung strategi program pemuliaan pohon, penanaman maupun pembangunan sumber benih berkualitas genetik unggul saat ini maupun di masa datang.

\section{Bahan dan Metode}

Penelitian dilakukan dari Nopember 2011 sampai April 2012 di Laboratorium Bioteknologi dan Analisis Tanaman Fakultas Pertanian Universitas Padjadjaran, Jatinangor, Jawa Barat, Indonesia. Materi genetik yang digunakan adalah daun dari bibit progeni half-sib tetua Provenan Banjarnegara, Subang Kediri dan Kuningan yang tumbuh pada tegakan benih uji provenan. Jumlah masing-masing materi genetik sebanyak 40 sampel, sehingga total sampel sebanyak 160 sampel. Gambaran tegakan benih uji provenan seperti Gambar 1.

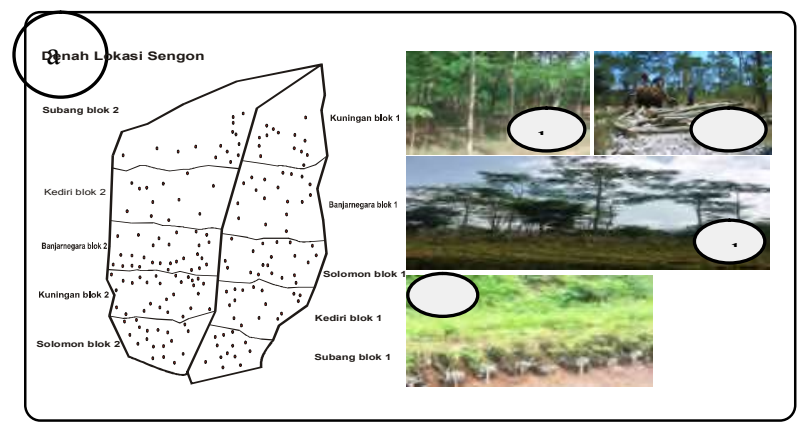

Gambar 1. Material genetik P. falcataria sebagai bahan penelitian

Keterangan : (a). sebaran tegakan benih uji provenan $P$. falcataria setelah seleksi; (b). tegakan benih umur 4 tahun; (c). aktivitas mass selection; (d). kondisi tegakan benih setelah seleksi; (e). bibit progeni half-sib umur 3 bulan

Diversitas genetik dianalisis melalui marka RAPD (Random Amplified Polymorphic DNA) melalui tahapan sebagai berikut :

\section{Isolasi DNA}

CTAB (Cationic Hexaecyl Trimethyl Amonium Bromide) digunakan sebagai metode isolasi DNA. Sampel daun $2 \mathrm{~g}$ dihancurkan pada pestel steril dengan CTAB $450 \mu \mathrm{l}$ (dua tahap $250 \mu \mathrm{l}$ dan $200 \mu \mathrm{l}$ ) dan SDS $10 \% 50 \mu$ l. Larutan diinkubasi dalam penangas air bersuhu $65^{\circ} \mathrm{C}$ selama 15 '. Ditambahkan potassium asetat 5 M sebanyak $100 \mu \mathrm{l}$, fenol $200 \mu \mathrm{l}$, kloroform $682 \mu \mathrm{l}$ dan isoamilalkohol $18 \mu \mathrm{l}$. Supernatan dipisahkan dengan kotoran melalui sentrifugasi pada kecepatan 12000 rpm selama 5'. DNA dipekatkan potassium asetat
5 M sebanyak $70 \mu \mathrm{l}$ dan isopropanol $550 \mu$ dan disentrifugasi pada kecepatan 12000 rpm selama 5 . Pellet DNA dicuci dengan menambahkan alkohol 70\% sebanyak $500 \mu \mathrm{l}$ dan disentrifugasi dengan kecepatan 12000 selama 3'. Pelet DNA dikeringkan pada oven 50 ${ }^{\circ} \mathrm{C}$ selama 10'. Pelet yang telah kering ditambahkan larutan buffer TE sebanyak $50 \mu$ dan diinkubasi pada suhu $37^{\circ} \mathrm{C}$ selama $30^{\prime}$.

\section{Uji Kualitas DNA}

Kualitas DNA hasil ekstraksi dielektroforesis pada gel agarose berkonsentrasi $1 \% \quad(\mathrm{~b} / \mathrm{v})$. Elektroforesis pada tegangan 100 volt selama 30'. Hasil elektroforesis direndam pada larutan Ethidium bromida (EtBr) dengan konsentrasi 1\% (v/v) selama 30' dan dibersihkan pada nanopure water selama 10'. Pita DNA hasil isolasi diamati dengan menggunakan alat UV transilluminator.

\section{Amplifikasi DNA dengan Teknik PCR-RAPD}

Proses amplifikasi dengan menggunakan 4 komponen utama yang dicampurkan ke dalam microtube ukuran $0,2 \mathrm{ml}$. Untuk 1 kali sampel reaksi digunakan 2,5 $\mu \mathrm{l} \mathrm{H}_{2} \mathrm{O}, 7.5 \mu \mathrm{l}$ Go Taq Green Master Mix Qit, $1.5 \mu$ praimer dan $2.0 \mu \mathrm{l}$ DNA.

Praimer yang digunakan sebanyak 4 praimer hasil seleksi dari 10 praimer dari operon technology, yakni : OPK-19 (sekuen 5'-3' CACAGGCGGA), OPP-6 (sekuen 5'-3' GTGGGCTGAC), OPA-10 (sekuen 5'-3' GTGATCGCAG) dan OPA-11 (sekuen 5'-3' CAATCGCCGT).

Proses PCR untuk praimer OPK-19 melalui tahapan pre-denaturation $95^{\circ} \mathrm{C}$ selama $10^{\prime} 1$ siklus, dentaturation $95^{\circ} \mathrm{C}$ selama 1' 35 siklus, annealing $37^{\circ} \mathrm{C}$ selama 3' 35 siklus, extension $72^{\circ} \mathrm{C}$ selama 2' 35 siklus dan final extension $72^{\circ} \mathrm{C}$ selama $10^{\prime} 1$ siklus. Tahapan Proses PCR untuk praimer OPP-6, OPA-10 dan OPA11 adalah : pre-denaturation $95^{\circ} \mathrm{C}$ selama 2 ' 1 siklus, dentaturation $95^{\circ} \mathrm{C}$ selama 1' 40 siklus, annealing $35^{\circ} \mathrm{C}$ selama 1' 40 siklus, extension $72^{\circ} \mathrm{C}$ selama $2^{\prime} 40$ siklus dan final extension $72^{\circ} \mathrm{C}$ selama $5 \% 1$ siklus.

\section{Elektroforesis}

Gel agarose yang digunakan berkonsentrasi $1 \%$ (v/v) yang dilarutkan dalam buffer TBE 0,5 X yang mengandung EtBr $625 \mathrm{ug} / \mathrm{ml}$. DNA ditambah loading buffer sebanyak $1 / 2$ volume DNA hasil PCR dan dimasukkan ke dalam sumur sebanyak $4 \mu$ l. Marker menggunakan loading dye $1 \mathrm{~kb}$. Elektroforesis berlangsung pada tegangan 70 volt selama 1 jam.

\section{Pewarnaan DNA dan Pemotretan}

Pewarnaan menggunakan Ethidium Bromide $(E t B r)$ sebanyak $10 \mu \mathrm{l}$ yang dicampur dengan 
akuades sebanyak $200 \mathrm{ml}$. Proses pewarnaan DNA dilakukan selama 30' dan pencucian selama 10' dalam aquadest. Gel hasil pewarnaan dilihat di atas sinar UV yang memiliki panjang gelombang 312 nm. Pemotretan dilakukan melalui PC computer dengan menggunakan software Syngene.

\section{Analisis Data}

Data pola pita hasil analisis DNA diterjemahkan ke dalam data biner dengan ketentuan nilai nol (O) untuk tidak terdapat pola pita atau DNA absence dan satu (1) untuk adanya pita DNA pada satu posisi yang sama dari individu yang dibandingkan. Hasil skoring pita DNA dianalisis dengan bantuan program komputer Biosys-2 (Swofford dan Selander, 1997) untuk menduga parameter variasi genetik berikut uji statistiknya. Pola kekerabatan dianalisis berdasarkan metode UPGMA (Unweight Pair-Group Method Arithmetic) dengan bantuan Software NTSys versi 2.02 (Rohlf, 2000).

\section{Hasil dan Pembahasan}

\section{Jumlah Lokus dan Ukuran Fragmen DNA}

Hasil pengamatan terhadap struktur pola pita DNA diperoleh jumlah lokus dan ukuran fragmen yang berbeda untuk tiap primer yang digunakan. Jumlah total lokus yang teramati sebanyak 30 lokus, dimana jumlah lokus untuk masing-masing praimer adalah : OPK-19 sebanyak 9 lokus, OPP-6 sebanyak 6 lokus, OPA-10 sebanyak 8 lokus dan OPA-11 sebanyak 7 lokus. Perbedaan juga terlihat pada ukuran fragmen pada masing-masing praimer. Ukuran fragmen praimer OPK-19 mendeteksi pita DNA antara 50 bp sampai 1000 bp, praimer OPP-6 mendeteksi pita DNA antara 200 bp sampai 600 bp, praimer OPA-10 mendeteksi pita DNA antara 200 bp sampai 1000 bp dan praimer OPA-11 mendeteksi pita DNA antara 150 bp sampai 600 bp. Contoh profil pola pita DNA RAPD dari empat praimer yang digunakan sebagaimana Gambar 2.

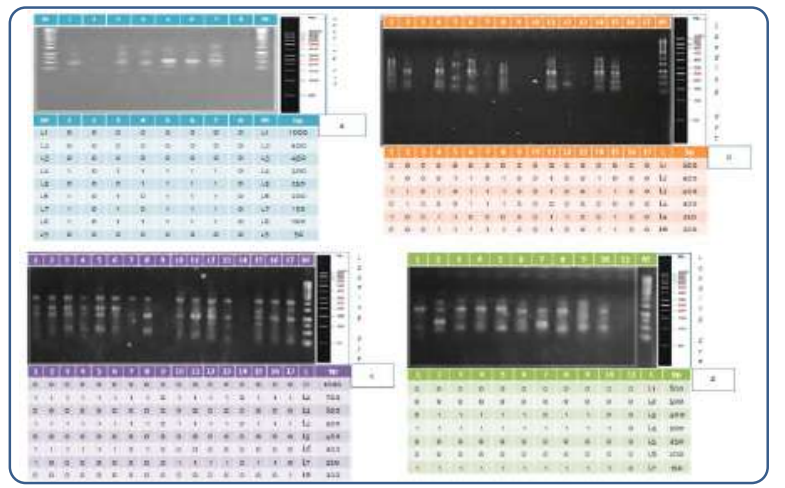

Gambar 2. Profil pola pita DNA (a) OPK-19; (b) OPP-6; (c) OPA-10; dan (d) OPA-11
Keterangan : 1,2,3 = individu; $\mathrm{M}=$ marker; $\mathrm{L}=$ lokus

Perbedaan jumlah dan ukuran fragmen keempat praimer disebabkan oleh perbedaan letak perlekatan praimer pada suatu genom individu. Grosberg (1996) menyatakan bahwa jumlah fragmen yang teramplifikasi oleh suatu praimer tergantung pada jumlah letak perlekatan praimer pada genom individu. Perbedaan terjadi karena masing-masing praimer memiliki urutan nukleotida yang berbeda satu dengan lainnya. Praimer OPP-6 memiliki tingkat efisiensi yang lebih tinggi dibandingkan ketiga praimer lainnya karena ukuran fragmen yang dihasilkan oleh praimer OPP-6 lebih pendek. Semakin pendek ukuran fragmen, maka semakin efisien reaksi amplifikasi (Weising et al., 1995).

Polimorfisme pola pita DNA dari keempat praimer sebagai penanda diversitas genetik disebabkan oleh perbedaan daerah pengikatan praimer oligonukleotida. Perbedaan urutan DNA diantara individu-individu pada daerah pengikatan praimer oligonukleotida menyebabkan terjadinya perbedaan-perbedaan (polimorfisme) pada pola larik yang dihasilkan dari proses amplifikasi. Perbedaan tersebut merupakan gambaran dari diversitas genetik.

\section{Diversitas Genetik Populasi Progeni Half-Sib $P$. falcataria Hasil Seleksi Ketahanan Boktor dan Riap Pertumbuhan}

Diversitas genetik populasi progeni half-sib $P$. falcataria setelah seleksi ketahanan boktor dan riap pertumbuhan hasil analisis Biosys-2 (Swofford dan Selander, 1997) disajikan pada Tabel 1. Tabel 1. memperlihatkan bahwa dengan jumlah sampel masing-masing sebanyak 40 individu pada level populasi diperoleh rata-rata pola pita polimorfik per lokus (PP/L) sebesar 1.8, persen lokus polimorfik (PPL) sebesar $77.50 \%$ dan heterosigositas harapan (He) sebesar 0.244.

Tabel 1. Jumlah sampel, rata-rata pola pita DNA per lokus, persen lokus polimorfik dan heterosigositas populasi progeni half-sib $P$. falcataria hasil seleksi ketahanan boktor dan riap pertumbuhan

\begin{tabular}{llcccc}
\hline No & Progeny Half-sib & $\mathrm{N}$ & $\mathrm{PP} / \mathrm{L}$ & $\mathrm{PPL}$ & $\mathrm{He}$ \\
\hline 1 & Banjarnegara & 40 & 1.9 & 83.30 & 0.283 \\
2 & Subang & 40 & 1.8 & 76.70 & 0.216 \\
3 & Kediri & 40 & 1.8 & 73.30 & 0.237 \\
$4 \quad$ Kuningan & 40 & 1.8 & 76.70 & 0.241 \\
\hline Rata-rata & 40 & 1.82 & 77.50 & 0.244 \\
\hline
\end{tabular}

Keterangan : $\mathrm{N}=$ jumlah sampel; $\mathrm{PP} / \mathrm{L}=$ rata-rata pola pita polimorfik per lokus; $\mathrm{PPL}=$ persen lokus polimorfik; $\mathrm{He}=$ heterosigositas harapan 
Diversitas genetik di dalam populasi progeni half-sib, menunjukkan bahwa progeni Provenan Banjarnegara memiliki diversitas genetik yang lebih tinggi dibandingkan progeni provenan lainnya. Hal ini diindikasikan oleh nilai paling tinggi pada $\mathrm{PP} / \mathrm{L}$ sebesar 1.9, PPL sebesar $83.30 \%$ dan He sebesar 0.283. Diversitas genetik terendah terlihat pada progeni provenan Kediri yang diindikasikan oleh rendahnya PP/L sebesar 1.8, PPL sebesar 73.30 dan He sebesar 0.237.

Diversitas genetik yang diprediksi berdasarkan proporsi lokus polimorfik (PPL) merupakan ukuran umum (Hattemer dan Melchior, 1993; Hattemer, 1991), sehingga dapat dikatakan bahwa diversitas genetik populasi progeni half-sib lebih tinggi dibandingkan di dalam populasi progeni half-sib, kecuali progeni Provenan Banjarnegara. Hal tersebut selaras dengan diversitas genetik berdasarkan nilai heterosigositas (He). Nilai heterosigositas terklasifikasi sedang baik populasi progeni half-sib maupun di dalam populasi progeni half-sib yang mengacu Na'iem (2001), berdasarkan nilai heterosigositas bahwa nilai $\mathrm{He}>0,300$ tergolong besar, nilai $\mathrm{He}$ 2,000 - 3,000 tergolong sedang dan nilai $\mathrm{He}<2,000$ tergolong rendah.

Nilai heterosigositas harapan (He) baik pada populasi progeni half-sib maupun di dalam populasi progeni half-sib ternyata lebih tinggi daripada penelitian Thielges et al. (2001); Widyastuti (2007); Seido et al. (1993) yang memperoleh nilai $\mathrm{He}$ masing-masing sebesar $0.187,0.185$ dan 0.163 dengan penanda genetik RAPD. Namun, relatif sama dengan hasil penelitian isozim oleh Basyuni (1998) cit. Dwiyanti (2007) dengan nilai He 0.226; Gunawan (2005) dengan nilai He 0.235; Winarni (2003) dengan nilai He 0.22 dan Dwiyanti (2009) yang memperoleh nilai He sebesar 0.218.

Secara umum, diversitas genetik populasi progeni half-sib hasil seleksi ketahanan boktor dan riap pertumbuhan lebih tinggi dibandingkan jenis pohon hutan lainnya seperti : Acacia mangium dengan nilai He rata-rata 0.017 (Moran, et. al., 1989), Acacia auriculiformis dengan nilai He sebesar 0.081 (Wickneswari dan Norwati, 1993), Pinus merkusii dengan nilai $\mathrm{He}$ sebesar 0.058 (Changtragoon dan Finkeldey, 1995), Shorea spp. dengan nilai He sebesar 0.129 (Cao et al., 2009), Toona sinensis dengan nilai $\mathrm{He}$ sebesar 0.155 (Hidayat et al., 2010), Diospyros celebica dengan nilai He sebesar 0.133 (Restu dan Mukrimin, 2005) dan Araucaria cunninghumii dengan nilai rata-rata $\mathrm{He}$ sebesar 0.270 (Widyatmoko et al., 2010).

Diprediksi diversitas genetik progeni half-sib tergolong sedang disebabkan oleh faktor seleksi, sistem perkawinan (mating system), sejarah populasi dan spesies, sebaran populasi awal, aliran gen dan persilangan tetua di dalam tegakan benih (Hamrick dan Godt, 1996). Progeni half-sib merupakan hasil persilangan antar tetua terseleksi tahan boktor dan riap pertumbuhan, akibat seleksi masa pada tegakan benih, aktivitas seleksi merupakan faktor yang dapat menurunkan diversitas genetik (Finkeldey, 2005).

Hasil observasi lapangan diperoleh informasi bahwa tegakan benih $P$. falcataria masih terlihat fenomena cepat berbunga dan lambat berbunga. Ketidakseragaman dalam pembungaan diprediksi akan berpengaruh terhadap sistem perkawinan (mating system). Akibatnya, akan berpengaruh pula pada diversitas genetik progeni half-sib. Berdasarkan sejarah, diprediksi bahwa $P$. falcataria memiliki diversitas genetik yang rendah sebagaimana dinyatakan Heyne (1987), di Pulau Banda sengon ditemukan oleh Teysman dan dibawa ke Kebun Raya Bogor, dari Kebun Raya ini sejak 1871 tersebar di seluruh Nusantara. Sejarah penyebaran $P$. falcataria akan berimplikasi terhadap diversitas genetik progeni half-sib yang diteliti.

\section{Jarak Genetik dan Pola Kekerabatan Populasi Progeny Half-Sib $P$. falcataria Hasil Seleksi Ketahanan Boktor dan Riap Pertumbuhan}

Jarak genetik merupakan salah satu parameter yang dapat memberikan indikasi adanya hubungan kekerabatan antar populasi progeni half-sib. Ukuran jarak genetik yang sering digunakan antara lain dikemukan oleh Nei (1972) dan Gregorius (1974) (Liengsiri et al., 1990). Pengukuran jarak genetik antar populasi dapat dilakukan berdasarkan lokus maupun gene pool. Tabel 2. merupakan matriks jarak rata-rata gene pool menurut kedua metode tersebut.

Tabel 2. Matriks jarak genetik rata-rata (do) menurut Gregorius (1974) di bawah diagonal dan (Dj) Nei (1972) di atas diagonal populasi progeni half-sib $P$. falcataria

\begin{tabular}{lcccc}
\hline Progeni Half-sib & $\begin{array}{c}\text { Banjar- } \\
\text { negara }\end{array}$ & Subang & Kediri & $\begin{array}{c}\text { Kuni- } \\
\text { ngan }\end{array}$ \\
\hline Banjarnegara & $* * * *$ & 0,020 & 0,071 & 0,148 \\
Subang & 0,095 & $* * * *$ & 0,117 & 0,175 \\
Kediri & 0,173 & 0,201 & $* * * *$ & 0,082 \\
Kuningan & 0,249 & 0,246 & 0,168 & $* * * *$ \\
\hline
\end{tabular}

Jarak genetik populasi progeni half-sib berkisar antara 0.095 - 0.249 menurut Nei (1972) dan berkisar antara $0.020-0.175$ menurut Gregorius (1974). Jarak genetik terendah terjadi antara progeni half-sib Banjarnegara dengan progeni halfsıb Subang baik menurut Nei (1972) maupun 
Gregorius (1974). Perbedaan jarak genetik pada kedua metode tersebut terjadi pada jarak genetik tertinggi. Dalam hal ini jarak genetik paling tinggi antara progeni half-sib Provenan Kuningan dengan Subang Menurut Gregorius (1974) dan antara progeni half-sib Provenan Kuningan dengan Banjarnegara menurut Nei (1972). Tinggi rendahnya jarak genetik merupakan indikasi pola kekerabatan, semakin rendah jarak genetik semakin tinggi kekerabatan.

Secara umum jarak genetik menurut Nei (1972) lebih tinggi dibandingkan jarak genetik menurut Gregorius (1974). Pola hubungan antara jarak genetik menurut Nei (1972) dan Gregorius (1974) memiliki keselarasan dengan keeratan antar metode sangat tinggi. Keeratan tersebut ditunjukkan oleh nilai determinan sebesar 0.7861 .

Hasil analisis jarak genetik dengan menggunakan metode Nei (1972) dan Greigorius (1974) pada penelitian ini ternyata berbeda dengan hasil yang diperoleh oleh (Sunarya, 2005) pada jenis yang sama dengan menggunakan marka insozim yang memperoleh hubungan negatif antara kedua metode tersebut dengan korelasi yang rendah sebesar 0.1706. Berbeda halnya dengan hasil penelitian Wulan (2003) yang memperoleh hasil yang sama dengan penelitian ini dengan menggunakan isozim dan korelasinya sebesar 0.7716 .

Berbagai kondisi lingkungan dapat menyebabkan dua populasi yang semula identik berangsur-angsur berubah dan berada atau memiliki jarak genetik yang semakin membesar. Salah satu kondisi yang paling ekstrim adalah adanya mekanisme isolasi yang tidak memungkinkan terjadinya pertukaran gen. Mekanisme isolasi ini antara lain ditunjukkan dengan adanya gejala poliploidi, perbedaan waktu berbunga dan berbuah, mekanisme penyerbukan tertentu (misal : inkompatibilitas) dan letak geografis yang berjauhan (Wright, 1976).

Pola Klaster Populasi Progeni Half-Sib $P$. falcataria Hasil Seleksi Ketahanan Boktor dan Riap Pertumbuhan

Rata-rata jarak gene pool digunakan juga untuk analisis kelompok dengan menggunakan metode UPGMA melalui program NTSys versi 2.02. Hasil analisis UPGMA berupa dendrogram yang menggambarkan pola klaster/kekerabatan berdasarkan Nei (1972) terlihat pada Gambar 3.

Pola klaster/kekerabatan populasi progeni halfsib terbagi kedalam tiga klaster/kelompok. Klaster/kelompok pertama terdiri dari progeni halfsib Provenan Banjarnegara dan Subang, kelompok kedua progeni half-sib Provenan Kediri dan kelompok ketiga progeni half-sib Provenan Kuningan. Hasil klastering/pengelompokan tidak dapat menjelaskan pola distibusi geografis. Hal ini terlihat dari mengelompoknya progeni half-sib Provenan Banjarnegara dengan progeni half-sib Provenan Subang pada klaster yang sama atau memiliki kekerabatan terdekat. Padahal secara geografik kedua provenan tersebut relatif berdekatan. Kekerabatan terjauh terlihat antara progeni half-sib Provenan Banjarnegara dengan progeni half-sib Provenan Kuningan. Pola kekerabatan populasi progeni half-sib hasil seleksi ketahanan boktor dan riap pertumbuhan berbeda dengan pola kekerabatan hasil penelitian (Sunarya, 2005) melalui marka isozim, dimana pada populasi tegakan benih $P$. falcataria tersebut kekerabatan terjauh terjadi antara Provenan Subang dengan Kediri.

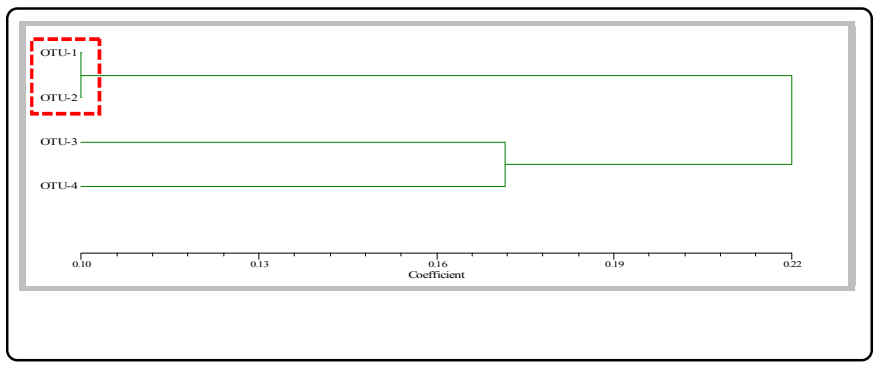

Gambar 3. Dendrogram jarak genetik populasi progeni half-sib P. falcataria terseleksi tahan boktor dan pertumbuhan tinggi berdasarkan Nei (1972)

Keterangan : OTU1 = Progeny Half-sib Banjarnegara; OTU2 = Progeny Half-sib Subang; OTU3 = Progeny Halfsib Kediri; OTU4 = Progeny Half-sib Kuningan

\section{Kesimpulan}

Diversitas genetik populasi progeni half-sib $P$. falcataria hasil seleksi ketahanan boktor dan riap pertumbuhan tergolong sedang dengan nilai heterosigositas harapan (He) sebesar 0.244. Diversitas genetik populasi lebib tinggi daripada di dalam populasi, kecuali progeni half-sib Banjarnegara dengan diversitas genetik tertinggi (PP/L=1.9, PPL $=83.30 \%$ dan $\mathrm{He}=0.283)$.

Jarak genetik berkisar antara 0.095-0.249 menurut Nei dan antara 0.02-0.175 menurut Gregorius dengan jarak genetik terendah antara progeni half-sib Provenan Banjarnegara dengan progeni half-sib Provenan Subang. Jarak genetik tertinggi berbeda menurut kedua metode tersebut dan jarak genetik menurut metode Nei lebih tinggi daripada Gregorius. Kedua metode jarak genetik memiliki korelasi positif dengan nilai keeratan $78.61 \%$. 
Populasi progeni half-sib terbagi menjadi 3 klaster/kelompok. Klaster pertama progeni half-sib Provenan Banjarnegara dan Subang, klaster kedua progeni half-sib Provenan Kediri dan klaster ketiga progeni half-sib Provenan Kuningan. Kekerabatan terendah antara progeni half-sib Provenan Banjarnegara dengan Subang, sehingga tidak dapat menjelaskan pola distribusi geografis. Kekerabatan tertinggi antara progeni half-sib Provenan Banjarnegara dengan progeni half-sib Provenan Kuningan.

\section{Ucapan Terima Kasih}

Ucapan terima kasih disampaikan kepada DP2M Dikti atas bantuan biaya penelitian melalui Hibah Kompetitif Strategi Nasional Tahun 2010 dengan judul Evaluasi Genetik dan Morfologi Keturunan Populasi Hasil Seleksi Sumber Benih Sengon (Paraserianthes falcataria (L) Nielsen) Tahan Boktor (Xystrocera vestipa) dan Produktifitas Tinggi.

\section{Daftar Pustaka}

Balai Perbenihan Tanaman Hutan Jawa-Madura. 2009. Direktori Sumber Benih Tanaman Hutan Bersertifikat. Departemen Kehutanan Direktorat Jenderal Rehabilitasi Dan Perhutanan Sosial. Jakarta.

Cao, C.P., Gailing, O., Siregar, I.Z., Siregar, U.J, and Finkeldey, R. 2009. Genetic variation in nine Shorea species (Dipterocarpaceae) in Indonesia revealed by AFLPs. Tree Genetics and Genomes. 5: 407-420.

Changtragoon, S. and Finkeldey, R. 1995. Patterns of genetic variation and characterization of the mating system of Pinus merkusii in Thailand. Forest Genetics. 2:87-97.

Dwiyanti, F.G. 2009. Keragaman Sengon Solomon (Paraserianthes falcataria (L) Nielsen) Pada Uji Keturunan Di Hutan Percobaan Cirangsad. Departemen Silvikultur Fakultas Kehutanan Institut Pertanian Bogor. Bogor. www.google. scholar.repository.IPB.ac.id.

Falconer D.S. 1989. Introduction to Quantitative Genetics Third Edition. John Wiley \& Sons, Inc. New York. Pp. 4- 23.

Finkeldey, R., and Hattemer, H.H. 1993. Gene resources and gene conservation with emphasis on tropical forests. FAO/IBPGR Plant Genetic Resources Newsletter 94/95: 5-10.

Finkeldey R. 2005. Pengantar Genetika Hutan Tropis. Djamhuri E, Siregar IZ, Siregar UJ, Kertadikara AW, penerjemah. Bogor: Fakultas Kehutanan, Institut Pertanian Bogor. Terjemahan dari: An Indtroduction to Tropical Forest Genetics.

Grattapaglia, D. and R.R. Sederoff. 1992. Genetic linkage maps of Eucalyptus grandis and E. urophylla using a pseudo-testcross mapping strategy and RAPD markers. Genetics 137:1121-1137.
Gregorius, H.R. 1974. The concept of genetic diversity and its formal relationship to heterozygosity and genetic distance. Math. Biosci. 41: 253-271.

Grosberg, R.K., Leviton, D.R. dan Comeron, B.B. 1996. Chraracterization of Genetic Structure and Genealogis RAPD-PCR Marker : A Random Primer for The Novice and Nervous, J.D and Palumbi, S.R., Molecular Zoology Advances, Strategies and Protocols. John Willey and Sons Inc. Publication. New York.

Gunawan, R. 2005. Struktur dan variasi genetik bibit tanaman sengon, mangium, durian dan rambutan untuk GNRHL berdasarkan isoenzim. Bogor: Departemen Manajemen Hutan, Fakultas Kehutanan. Institut Pertanian Bogor.

Hamrick, J.L. and Godt, M.J. 1996. Effect of life history traits on genetic diversity in plant species. Philosophical Transection Biological Science. 351: 129-1298.

Hardiyanto, E.B. 1994. Suplemen Bahan Kuliah Kursus Pemuliaan Pohon Hutan. Kursus Pemuliaan Pohon Hutan Wanagama I 22 Agustus - 3 September 1994. Yogyakarta.

Hattemer, H.H. 1991. Measuring genetic variation. In Muller-Starck, G. and Ziehe, M.E. (eds.): Genetic Variation in European Population of Forest Trees. Frankfurt/M.: Sauerländer's Verlag. pp.2-19.

Hattemer, HH and GH, Melchior. 1993. Genetics and its application to tropical forestry. In Pancel, (L) (ed.) : Tropical Forestry Handbook. Volume 1. Berlin etc. : Springer. PP. 333-380.

Heyne K. 1987. Tumbuhan Berguna Indonesia. Jilid ke II cetakan ke-1. Badan LITBANG Kehutanan Jakarta. Jakarta.

Hidayat, Y., Murdaningsih, H.K., Suseno, A. dan Siregar, IZ. 2010. Surian (Toona sinensis) : Ditinjau dari aspek ekologi, variasi genetik, silvikultur dan pemuliaan. Unpad Press. Bandung. p: 236.

Irawanti, S., K.L. Ginoga, A. Prawestisuka, and D. Race. 2014. Commercialising community forestry in Indonesia: Lesson about barrier opportunity in Central Java. Small-Scale Forestry 13: 515-526.

Ishiguri, F., T. Hiraiwa, K. Iizuka, S. Yokota, D. Priadi, N. Sumiasri, and N. Yoshizawa. 2009. Radial Variation of Anatomical Characteristics in Paraserianthes Falcataria Planted in Indonesia. IAWA Journal, Volume 30, Issue 3, pages 343-352.

Iskandar, J. and J.F. Ellen. 2000. The Contribution of Paraserianthes (Albizia) falcataria to Sustainable Swidden Management Practices among The Baduy of West Java. Human Ecology 28(1).

Liengsiri, C., C. Piewlang, T.J.B. Boyle. 1990. Starch Gel Electroforesis of Tropical Tree, A Manual ASEANCanada Forest Tree Seed Centre. Muak Lek. Saraburi.

Moran, G.F., Mouna, O. and Bell, J.C. 1989. Acacia mangium: a tropical forest tree of the coastal lowland wih low genetic diversity. Evolution 43: 231-235.

Muslyza Che Hussin, Jamaludin Kasim, Nur Farahin Yusoff, Nor Farhana Jasmi, and Siti Nadzirah Misfar. 2014. Effect of three portion and distance from pith on the basic density, fiber properties and chemical 
composition of Albizia falcataria Wood. International Journal of Latest Research in Science and Technology. Volume 3, Issue 6: Page No.187-191, November-December 2014. Diakses dari http://www.mnkjournals.com/ijlrst.htm.

Nai'em, M. 2001. Genetic Variation of Shorea leprosula Miq. In Three Population in Indonesia : Implication for Ex-Situ Conservation. Bulletin Kehutanan. Jogyakarta.

Nei, M. 1972. Analysis of Gene Diversity in Subdivided Populations. Proceeding of the National Academy of Sciences. USA. 70: $3321-3323$.

Nordahlia, A.S., S.C. Lim, H. Hamdan, and U.M.K. Anwar. 2014. Wood properties of selected plantation species: Tectona grandis (teak), Neolamarckia cadamb (kelempayan/laran), Octomeles sumatrana (binuang), and Paraserianthes falcataria (batai). Timber Technology Bulletin No 54: 1-6.

Restu, M. dan Mukrimin. 2005. Keragaman Genetik Ebony (Diospyros celebica Bkh.) Provenan amaro Kabupaten Barru. Jurnal Hutan dan Masyarakat 2(3): 263-267.

Rimbawanto, A. 2008. Pemuliaan Tanaman dan Ketahanan Penyakit pada Sengon. Makalah Workshop Penanggulangan Serangan Karat Puru pada Tanaman Sengon 19 November 2008. Balai Besar Penelitian Bioteknologi dan Pemuliaan Tanaman Hutan. Yogyakarta.

Rohlf, F.J. 2000. NT SYS-pc: Numerical Taxonomy and Multivariate analysis System Version 2.1. User Guide. Department of Ecology and Evolution State University of New York.

Seido K, Widyatmoko AYPBC, and Nursinggih G. 1993. Genetic Variation at Foir Allozyme Loci in (Paraserianthes falcataria (L) Nielsen. Forest Tree Improvement Project Technical Report. Yogyakarta.

Sunarya. 2005. Keragaman pada Karakter Kuantitatif, Isozim dan Aktifitas Tripsin Inhibitor Sengon (Paraserianthes falcataria (L) Nielsen) pada Beberapa
Uji Provenans Di Jawa Barat. Ilmu Pengetahuan Kehutanan IPB.

Swofford DL, and Selander RB. 1997. BIOSYS-2 : A Computer Program for The Analysis of Allelic Variation in Genetics. User's Manual. Department of Genetics and Development, University of Illionois at Urbana-Champaign, Urbana, Illinois. USA.

Thielges BA, Sastrapradja SD, Rimbawanto A. 2001. In situ and ex situ conservation of commercial tropical trees. Yogyakarta: Departement of Forest Science, Faculty of Forest, Gadja Mada University.

Weising, K.H., A.R. Kubelik, K.J. Livak, J.A. Rafalski and S.V. Tingey. 1995. DNA polymorphism amplified by arbitari primers are useful as genetic markers. Nucleic Acid Research. 18(22) : 6531-6535.

Widyastuti DE. 2007. Keragaman genetik dengan penanda RAPD, fenotipa pertumbuhan dan pendugaan heritabilitas pada sengon (Paraserianthes falcataria (L.) Nielsen) [tesis]. Bogor: Program Pascasarjana, Institut pertanian Bogor.

Widyatmoko, A.Y.P.B.C., E.S.P. Lejo, A. Prasetyaningsih dan A. Rimbawanto. 2010. Keragaman Genetik Populasi Araucaria cunninghumii Menggunakan Penanda RAPD (Random amplified Polymorphic DNA). Jurnal Pemuliaan Tanaman Hutan 4(2): 63-77.

Wikneswari, R, and Norwati, M. 1993. Genetic diversity of natural populations of Acacia auriculiformis. Australian Journal of Botany 41: 65-77.

Winarni, I. 2003. Studi Keragaman Aktivitas Tripsin Inhibitor dan Keragaman Genetik Isoenzim Pohon Plus Sengon (Paraserianthes falcataria (L.) Nielsen) pada Hutan Rakyat Di Jawa Barat. Institut Pertanian Bogor.

Wulan R. 2003. Struktur dan Keragaman Genetik Populasi Sengon (Paraserianthes falcataria (L) Nielsen) pada Hutan Rakyat Di Jawa. Institut Pertanian Bogor.

Wright, JW. 1976. Introduction to forest genetics. Acadenic Press. New York. 